Letter to editor

\title{
USAL Agronomy, Research to Face the Challenge.
}

\author{
Paula Ortiz ${ }^{1} \&$ Sebastián Felgueras ${ }^{2}$ \\ 1- Vicerrectora de Investigación y Desarrollo, Universidad del Salvador (USAL). E-mail: \\ portiz@usal.edu.ar
}

2- Director Escuela de Agronomía, Instituto de Investigación en Agronomía, Universidad del Salvador (USAL). Email: sfelguer@usal.edu.ar

Research has various objectives in different institutions. We have a social role and, therefore, we believe that the integral formation of a professional should contribute to the society in which he lives. That is, from our point of view, the purpose of Research and the answer to why it is important to investigate (Scholes et al 2010; Hernández et al 2010). Right there is where the three pillars of this university are complementary: in Teaching, students receive the knowledge and questions of the specific discipline; Research provides students with the opportunity to awaken their curiosity; and investigation results go back to society through Extension. It is a circle (Aramayo, 2006).

In the School of Agronomy, though not very different from other areas, we decided to focus research on two aspects. On the one side, there is the micro, which is related to the curricular area in which the student is inserted and even comes from a student's initiative in a chair. And then, there is the macro, which is an investigation that has a whole program, which is usually inserted into a synergy network with other universities or different departments of the university, where the student is later on integrated (Hernández et al 2010). Therefore, we have two ways to investigate: that born from the student in the classroom which ends up generating a research program, or that we institutionally propose as an axis and then direct to students. It is an interrelationship between the management responsible for the development of the research unit and the student's own interest (Perez-Lindo, 2003).

The idea is to observe nature and ask questions to ourselves. But such questions have to be formulated in relation to certain challenges that we propose. We should not expect from anybody or ask anyone for the solution of problems, we should come up with such solution. Therefore, what are the challenges? We will not have food because there will be more people occupying more land, there will be more mouths to be fed but with lower production capacity, 
given by, among other factors, the advance of urbanization in detriment of the availability of resources.

What is research? It is addressing this challenge, seeking answers to give us a possible solution on how to produce more on less land in order to feed more people. We have a fundamental social role which is to give back to society what society asked from us: train professionals to respond to the challenges of our current and future society (Blake, 2006).

It is estimated that, by 2050, the world population will at least reach 10 billion people, a considerable leap if we compare it with the variable percentage growth over time and on the basis of the seven thousand five hundred million people that today require food.

Another variable, not less important, is to analyze population growth that will use more consistent urban areas for settlement. It is worth remembering that in 2010, for the first time in history, urban population exceeded rural population worldwide. This indicates the degree of changes in eating habits and increased requirements of prepared foods for consumption established by urban idiosyncrasies.

Likewise, challenges for the demand for energy are presented. More settlements, less oil, more power to be provided from alternative channels. One of them introduces a big question that must be resolved by taking advantage of biotechnological tools, but also from the ethical point of view. Should agricultural primary production be transformed into food or energy? Response and actions are undoubtedly on social actors and leaders of the immediate future.

Research is the answer to that curiosity for finding knowledge. But we must also give curiosity and knowledge a certain order, we must frame them in a strategic plan that involves us as a society.

In that observation of nature, and in identifying the challenges that society needs and will need answers for, we saw that, because of soybean production processes -which implode in southern Santa Fe and northern Buenos Aires- and for not having a proper land use on agricultural production, many cattle communities displaced by agriculture had to relocate in marginal lands (Anlló et al., 2006). Such livestock did not generate profitability and hence a social disorder took place because there was nothing to feed those animals. So, we looked for a solution: "triticale" (Bianchi et al, 2013.). Even though it is not a variety coveted by farmers since it has no great commercial expectations-and therefore its patents belong generally to the government or some university- it becomes an answer for those relocated family farming communities. This is one of the examples that is framed in the strategic vision for research in the Agronomy Research 
Institute, whose primary objective is to provide answers to society, seeking concrete tools that are adapted to regional situations (Anlló et al, 2006).

In order to achieve this goal, we need internal synergy to channel the necessary resources to carry out research.

The university takes research as one of the most important pillars, together with teaching and extension (Davidson, 2006). While USAL was born from humanities, so research was related mainly to such sciences, it was a huge challenge to generate core research in hard sciences, especially for their costs. The Research and Development Vice-presidency was then restructured, highlighting its badge on "what is research and how we should do it." In this sense, it was vital to manage research at the University, i.e., systematization and registration of ongoing research and human resources that are working on them. As a result, we came up with USAL Research Yearbook, an annual academic publication with the abstracts of research projects carried out at the university, among many other tools resulting from this management process (Schweinheim, 2006).

The USAL has very distinctive values: we are linked to social development, to our concept of what a Catholic university is in its role in society, and research serves to respond to the needs of a society that increasingly requires more answers. In the case of Agronomy: how to feed ten billion people in the coming decades.

\section{References}

Anlló, G., R. Bisang, \& M. Campi, 2008. Una revolución (no tan) silenciosa. Claves para repensar el agro en Argentina. Revista Desarrollo Económico N 190-191, Vol. 48, Julio-Diciembre 2008.

Aramayo, O., 2006. Manual de Planificación Estratégica, Universidad de Chile, Instituto de Comunicación e Imagen.

Bianchi, D., S. Felgueras, F. Pantuso, A. Boyadjian, \& E. Sarlinga, 2013. Identificación de genotipos superiores en líneas avanzadas de triticale (x Triticosecale Wittmack). Revista de la Facultad de Agronomía y Ciencias Agroalimentarias UM - Editorial Universidad de Morón -ISSN 1853-0206, 4: 27-37.

Blake, O. J., 2006. Origen, detección y análisis de las necesidades de capacitación. $2^{\text {a }}$ edición. Argentina: Editorial Macchi, 2006. 
Sustainability, Agri, Food and Environmental Research 3(2), 2015: 22-25 ISSN: 0719-3726

Davidson, F.J., 2000. La nueva dirección de proyectos: herramienta para una era de cambios. Ed. Granica.

Hernández Sampieri, R., C. Fernández Collado, \& P. Baptista Lucio, 2010. Metodología de la investigación. $4^{\mathrm{a}}$ edición. Editorial Mac Graw Hill.

Pérez Lindo, A. 2003 Política y gestión universitaria en tiempos de crisis. Documento de Trabajo $\mathrm{N}^{\circ}$ 108, Universidad de Belgrano, 2003.

En: http://www.ub.edu.ar/investigaciones/dt_nuevos/108_perez_lindo.pdf

Scholes, K., G. Johnson, \& R. Whittington, 2010._Fundamentos de estrategia. Traducción de F. J. Forcadell Martínez. Madrid: Editorial Pearson Educación.

Schweinheim, G.F.F., 2010. Elementos para una nueva teoría del desarrollo. Revista Portes Año $16 \mathrm{~N}^{\circ} 28$. Asociación de Administradores Gubernamentales. 